\title{
Inhibition of Apical $\mathrm{Na}^{+}$Channels in Rabbit Cortical Collecting Tubules by Basolateral Prostaglandin $\mathrm{E}_{\mathbf{2}}$ Is Modulated by Protein Kinase C
}

\author{
Brian N. Ling, “ Kenneth E. Kokko, ${ }^{\star}$ and Douglas C. Eaton ${ }^{\star}$ \\ * Renal Division, Department of Medicine, Emory University School of Medicine and Veterans Administration Medical Center; and \\ ${ }^{\ddagger}$ Department of Physiology, Emory University School of Medicine, Atlanta, Georgia 30322
}

\begin{abstract}
We used the cell-attached patch clamp technique to investigate the interaction of exogenous prostaglandins (PG), intracellular $\left[\mathrm{Ca}^{2+}\right]_{i}$, and protein kinase $\mathrm{C}$ (PKC) on the high selectivity, 4 $\mathrm{pS} \mathrm{Na}^{+}$channel found in the principal cell apical membrane of rabbit cortical collecting tubule (CCT) cultures grown on collagen supports with $1.5 \mu \mathrm{M}$ aldosterone. Application of $0.5 \mu \mathrm{M}$ $\mathrm{PGE}_{2}$ to the basolateral membrane decreased mean $\mathrm{NP}_{0}$ (number of channels times the open probability) for apical $\mathrm{Na}^{+}$ channels by $46.5 \%(n=9)$. There was no consistent change in $\mathrm{NP}_{\mathrm{o}}$ after apical $0.5 \mu \mathrm{M} \mathrm{PGE}_{2}(n=12)$ or after apical or basolateral $0.5 \mu \mathrm{M} \mathrm{PGF}_{2 \alpha}(n=8)$. Release of $\left[\mathrm{Ca}^{2+}\right]_{i}$ stores with $0.25 \mu \mathrm{M}$ thapsigargin $(n=7)$, or activation of apical membrane PKC with apical 0.1 $\mu \mathrm{M} 4 \beta$-phorbol-12-myristate13-acetate $(n=5)$ or $10 \mu M$ 1-oleyl-2-acetylglycerol $(n=4)$ also decreased $\mathrm{NP}_{0}$. Depletion of $\left[\mathrm{Ca}^{2+}\right]_{i}$ stores $(0.25 \mu \mathrm{M}$ thapsigargin pretreatment $)(n=7)$ or inhibition of apical PKC (100 $\mu \mathrm{M}$ D-sphingosine pretreatment $)(n=8)$ abolished the

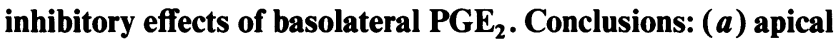
$\mathrm{Na}^{+}$transport in rabbit CCT principal cells is modulated by basolateral $\mathrm{PGE}_{2} ;(b)$ the mechanism involves release of $\mathrm{IP}_{\mathbf{3}^{-}}$ sensitive, $\left[\mathrm{Ca}^{2+}\right]_{i}$ stores; and $(c) \mathrm{Ca}^{2+}$-dependent activation of apical membrane PKC, which then inhibits apical $\mathrm{Na}^{+}$channels. (J. Clin. Invest. 1992. 90:1328-1334.) Key words: intracellular $\mathrm{Ca}^{2+} \bullet$ patch clamp • sphingosine • phorbol esters • principal cell
\end{abstract}

\section{Introduction}

Mammalian cortical collecting tubule $(\mathrm{CCT})^{1}$ principal cells are responsible for mineralocorticoid-dependent $\mathrm{Na}^{+}$reabsorption and, as such, represent the primary point for discretionary control of total body $\mathrm{Na}^{+}$balance (1-4). At a molecular level, this transepithelial $\mathrm{Na}^{+}$transport is regulated by alter-

A preliminary report of this work was presented at the American Society of Nephrology Annual Meeting, 17-20 November 1991 Baltimore, MD.

Address correspondence to Brian N. Ling, M.D., Emory University School of Medicine, Renal Division, 1364 Clifton Road, N.E., Atlanta, GA 30322.

Received for publication 13 January 1992 and in revised form 3 April 1992.

1. Abbreviations used in this paper: $\mathrm{CCT}$, cortical collecting tubule; $\mathrm{IP}_{3}$, inositol triphosphate; OAG, 1-oleyl-2-acetylglycerol; PKC, protein kinase C; PMA, 4 $\beta$-phorbol-12-myristate-13-acetate.

J. Clin. Invest.

(C) The American Society for Clinical Investigation, Inc.

$0021-9738 / 92 / 10 / 1328 / 07 \quad \$ 2.00$

Volume 90, October 1992, 1328-1334 ing the permeability of $\mathrm{Na}^{+}$channel proteins located in the principal cell apical membrane $(5,6)$.

The mechanisms for controlling $\mathrm{Na}^{+}$reabsorption can be thought of as a threefold hierarchy. The first level involves circulating hormones interacting with specific receptors at the basolateral (serosal) cell surface. The second level involves intracellular second messenger cascades that transduce the hormonal signal from the basolateral to the apical (luminal) membrane, where the primary control of $\mathrm{Na}^{+}$transport occurs. The third level involves molecular events confined to the local microenvironment of the apical membrane itself. Apical membrane-bound regulatory elements activated by cytosolic second messengers then directly modulate high selectivity $\mathrm{Na}^{+}$channel molecules.

Several groups have demonstrated that basolateral $\mathrm{PGE}_{2}$ exposure (first level or hormonal control) inhibits $\mathrm{Na}^{+}$reabsorption in microperfused rabbit CCT (7-11). Studies by Marver (12) and Stokes (13) suggest that inhibition of $\mathrm{Na}^{+}$ transport in rabbit CCT by basolateral $\mathrm{PGE}_{2}$ occurs at the apical $\mathrm{Na}^{+}$entry step (i.e., $\mathrm{Na}^{+}$channel), rather than at the basolateral $\mathrm{Na}^{+}$exit step $\left(\mathrm{Na}^{+}, \mathrm{K}^{+}\right.$-ATPase). Hebert et al. have shown that this inhibitory response to exogenous $\mathrm{PGE}_{2}$ is dependent on the release of intracellular $\mathrm{Ca}^{2+}$ stores (second level or second messenger control ) (11). Activation of the $\mathrm{Ca}^{2+}$-dependent enzyme, protein kinase $\mathrm{C}(\mathrm{PKC})$ also inhibits sodium absorption in isolated rabbit CCT $(12,14)$. Previously, we have shown that feedback-inhibition of single, high selectivity $\mathrm{Na}^{+}$channel activity in amphibian distal nephron cells (A6) is mimicked by activation of PKC in the apical membrane, but not the basolateral membrane, and is reversed by PKC inhibition (third level control or local microenvironmental control) (15).

We have recently characterized sodium-permeable channels present in the principal cell apical membranes of rabbit CCT grown in primary culture (3). The low conductance (4 pS) channel has all the physiologic properties predicted from studies of macroscopic $\mathrm{Na}^{+}$absorption in microperfused rabbit CCT, namely high $\mathrm{Na}^{+}$selectivity, mineralocorticoid-dependence, amiloride-sensitivity, and long mean open times (seconds). The present study examines inhibition of $\mathrm{Na}^{+}$reabsorption in the rabbit CCT by exogenous $\mathrm{PGE}_{2}$ at the level of the high selectivity $\mathrm{Na}^{+}$channel using patch clamp methodology and rabbit CCT primary cultures. We also investigate the role of intracellular $\mathrm{Ca}^{2+}$ and protein kinase $\mathrm{C}$ in $\mathrm{PGE}_{2}$-induced inhibition of principal cell $\mathrm{Na}^{+}$channels.

\section{Methods}

Preparation of rabbit cortical collecting tubule primary cultures. As previously described, kidneys were dissected from New Zealand white rabbits (1-2 kg) in ice-cold Hepes-buffered saline solution containing (mM): $118 \mathrm{NaCl}, 4.7 \mathrm{KCl}, 1.25 \mathrm{CaCl}_{2}, 1.25 \mathrm{MgSO}_{4}, 1.18 \mathrm{KH}_{2} \mathrm{PO}_{4}, 10$ 
glucose, $20 \mathrm{Na}$ cyclamate, and 5 Hepes at pH $7.4(3,16-18)$. The renal cortex was separated and incubated for 60 minutes at $37^{\circ} \mathrm{C}$ (equilibrated with $4 \% \mathrm{CO}_{2}$ in air) in a solution containing: $4 \mathrm{ml}$ of Hepesbuffered saline, $0.25 \mathrm{ml}$ 10\% BSA, $6.2 \mathrm{mg}$ of collagenase (type I; Sigma Chemical Co., St. Louis, MO), and $4 \mathrm{ml}$ of RK-1 medium. RK-1 medium contains 50\% Ham's F-12 (by volume) and 50\% DME (high bicarbonate and glucose) supplemented with $5 \mathrm{mg} /$ liter transferrin, 5 $\mathrm{mg} /$ liter insulin, $0.05 \mu \mathrm{M}$ sodium selenite, and $0.05 \mu \mathrm{M}$ hydrocortisone, $\mathrm{pH}$ 7.4. The cell mixture was then washed three times by suspension in RK-1 media and pelleting at $150 \mathrm{~g}$ for $1.5 \mathrm{~min}$. CCT fragments were separated by one high speed centrifugation $(15,000-30,000 \mathrm{~g})$ in an isotonic mixture of $50 \%$ Percoll and saline.

CCT fragments, contained in the lower part of the Percoll F1 separation band, were plated at confluent density on permeable, glutaraldehyde-fixed collagen films attached to the bottoms of small lucite rings $(3,15,17,18)$. This sided preparation allows patch pipette access to the apical membrane, and separate control of the apical and basolateral bath compositions (Fig. 1). Cultures were incubated in RK-1 medium with $1.5 \mu \mathrm{M}$ aldosterone (Sigma Chemical Co.) at $37^{\circ} \mathrm{C}$ and gassed with $4 \% \mathrm{CO}_{2}$ in air. Penicillin $(100 \mathrm{U} / \mathrm{ml})$ and streptomycin $(100$ $\mu \mathrm{g} / \mathrm{ml}$ ) was present for the first 24-48 h. In 4-7 d, the culture monolayer reached confluency. Patch voltage clamp experiments were performed on days 7-14.

Patch clamp recording and analysis. Polygonal shaped principal cells of rabbit CCT primary culture monolayers were visualized with Hoffman modulation optics (Modulation Optics Inc., Greenvale, NY) mounted on a Nikon Diaphot-TMD inverted microscope (16). Patch pipettes were fabricated and cell-attached patches with gigaohm seal resistances (10-20 G $\Omega$ ) were obtained on principal cell apical membranes, as previously described $(3,17,18)$. Unitary channel current events were obtained using an List-Medical EPC-7 patch clamp (Medical Systems Corp., Greenvale, NY). Events were processed by a Digital Data Adaptor (DAS 601; Dagan Corp., Minneapolis, MN), recorded on a video cassette recorder (SL-HF860D; Sony Corp. of America, Park Ridge, NJ), and digitized using digitizing hardware (Scientific Solutions Inc., Solon, $\mathrm{OH}$ ) and an 80286 computer ( $200 \mu \mathrm{s} /$ point; low-pass filtered at $1 \mathrm{kHz}$ ). Analysis of data was performed on an IBM PC/AT using locally and commercially developed software (19).

All experiments were conducted at $37^{\circ} \mathrm{C}$ with a TC-202 temperature controller and PDMI-2 open perfusion micro-incubator (Medical Systems Corp.). Patch pipettes contained a physiologic saline solution (mM): $140 \mathrm{NaCl}$ (final $\mathrm{NaCl}$ concentration after titration to $\mathrm{pH} 7.4$ with $\mathrm{NaOH}$ ), $5 \mathrm{KCl}, 1 \mathrm{CaCl}_{2}, 1 \mathrm{MgCl}_{2}$, and 10 Hepes. The basic apical and basolateral bath compositions were the same as the patch pipette solution above.

When channels were too numerous to clearly distinguish the individual channel current levels by histogram, the amplitude of single channel events were measured from the actual patch clamp recordings. The total number of functional channels $(\mathrm{N})$ in the patch were preliminarily estimated by observing the number of peaks detected on current amplitude histograms. As a measure of high selectivity $\mathrm{Na}^{+}$channel activity, $\mathrm{NP}_{\mathrm{o}}$ (number of channels times the open probability) was calculated (19).

$$
\mathrm{NP}_{\mathrm{o}}=\sum_{\mathrm{n}=0}^{\mathrm{N}} \frac{\mathrm{n} \cdot \mathrm{t}_{\mathrm{n}}}{\mathrm{T}}
$$

$T$ is the total record time, $n$ is the number of channels open, and $t_{n}$ is the record time during which $n$ channels are open. Therefore, $\mathrm{NP}_{\mathrm{o}}$ can be calculated without making assumptions about the total number of channels in a patch or the open probability of a single channel.

$\mathrm{PGE}_{2}, \mathrm{PGF}_{2 \alpha}$, thapsigargin (Calbiochem Corp., San Diego, CA), 4 $\beta$-phorbol-12-myristate-13-acetate (PMA), 1-oleyl-2-acetylglycerol (OAG), $4 \alpha$-phorbol, and D-sphingosine (Sigma Chemical Co.) were of the highest commercial grade available. Appropriate solvent vehicles (dimethyl sulfoxide or ethanol) were added to control baths, and by themselves caused no change in $\mathrm{Na}^{+}$channel activity.
Experiments were conducted in a paired fashion with each cell-attached patch membrane acting as its own control. Data is reported as mean values $\pm \mathrm{SD}$.

\section{Results}

High selectivity 4-pS $\mathrm{Na}^{+}$channels were identified in apical cell-attached patches of principal cells of rabbit CCT primary cultures (3). This channel was distinguished from other $\mathrm{Na}^{+}$ permeable channels (i.e., low selectivity, $9 \mathrm{pS}$; and nonselective, $30 \mathrm{pS}$ ) by its lower unitary conductance, nonlinear current-voltage (I-V) relationship, longer mean open times and inward current (pipette to cell) at all applied potentials, $\mathrm{V}_{\text {app }}<+80 \mathrm{mV}$ (cell interior with respect to pipette interior) (3). In previous patch clamp studies of high selectivity $\mathrm{Na}^{+}$ channels in rabbit and rat CCT, and amphibian distal nephron cells (A6), large variability in baseline channel activity was observed between different patches $(3,15,20)$. Because of this, each cell-attached patch was used as its own control when proposed regulatory factors were added to the apical bath (outside the patch pipette) or basolateral bath (Fig. 1).

Exogenous, basolateral prostaglandin $E_{2}$ inhibits apical, high selectivity, $\mathrm{Na}^{+}$channels. In the cell-attached patch configuration, baseline channel activity was recorded at resting cell membrane potential (applied pipette potential, $\mathrm{V}_{\text {app }}=0 \mathrm{mV}$ ). The basolateral bath solution was then replaced with the same solution containing $\mathrm{PGE}_{2}$ (final concentration $0.5 \mu \mathrm{M}$ ). Within 1 min of exposure, the fraction of time that $\mathrm{Na}^{+}$channels spent in the open state decreased (Fig. $2 A$ ). Fig. $2 B$ plots channel activity (measured as the product of the number of channels times the open probability, designated $\mathrm{NP}_{\mathrm{o}}$ ) for the 3-min "control" recording period immediately before and the 3-min recording period occurring after $1 \mathrm{~min}$ of basolateral $\mathrm{PGE}_{2}$ application for nine separate cell-attached patch clamp experiments. A consistent decrease in $\mathrm{NP}_{0}$ was observed in all patches with mean $\mathrm{NP}_{\mathrm{o}}$ falling from $0.49 \pm 0.22$ to $0.26 \pm 0.18$

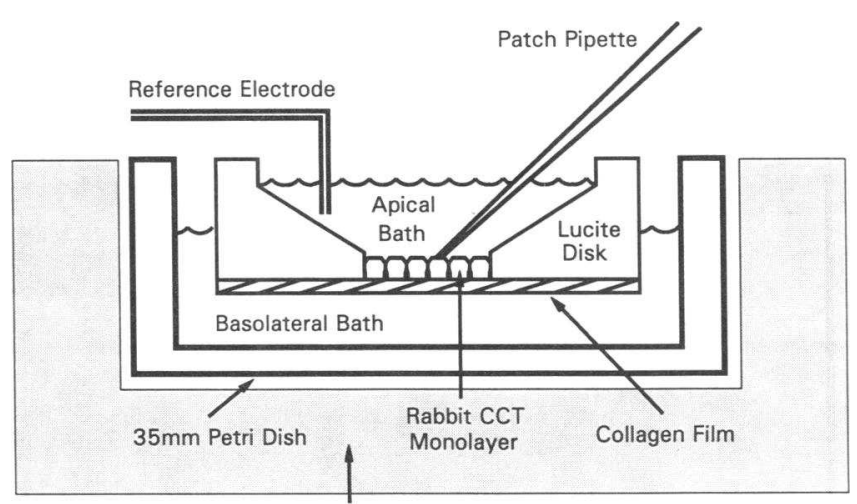

PDMI-2 Micro-Incubator

Figure 1. Bath exchange chamber. This schematic depicts a rabbit CCT primary culture monolayer grown on a collagen film attached to the bottom of a plastic ring. The petri dish, containing the plastic ring, is seated in a PDMI-2 Microincubator (see Methods) to maintain bath temperature at $37^{\circ} \mathrm{C}$. Apical and basolateral baths are separated by the collagen film and ring. Apical bath exchanges were conducted outside the patch pipette. 
A

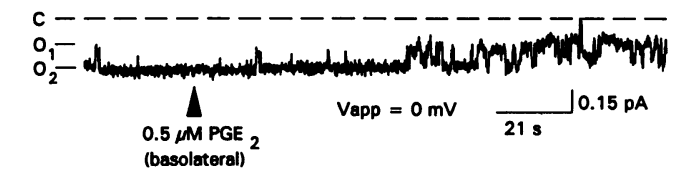

B

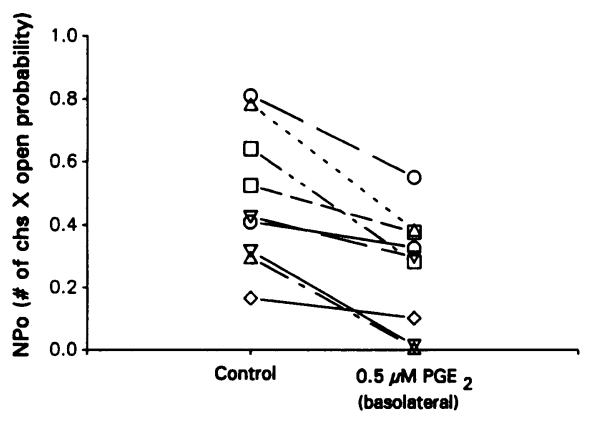

Figure 2. Effect of basolateral $\mathrm{PGE}_{2}$ on high selectivity $\mathrm{Na}^{+}$channels. (A) Cell-attached patch recording depicts inward $\mathrm{Na}^{+}$current (pipette to cell ) as downward deflections. This 3-min trace shows at least two $\mathrm{Na}^{+}$channels open under baseline conditions. Within $1 \mathrm{~min}$ of basolateral membrane exposure to $0.5 \mu \mathrm{M} \mathrm{PGE}_{2}$ (arrowhead), a marked decrease in open channel events can be seen. Horizontal bars mark zero current level ( $C$, closed state) and open channel current levels $(O$, open state $) . \mathrm{V}_{\text {app }}=0 \mathrm{mV}$, represents no applied pipette voltage to the patch membrane; i.e., resting membrane potential. Traces are recorded at a corner frequency of $1 \mathrm{kHz}$, sampled at $5 \mathrm{kHz}(200 \mu \mathrm{s}$ / point), and low pass filtered at $450 \mathrm{~Hz}$. $(B) \mathrm{Na}^{+}$channel activity, measured as $\mathrm{NP}_{\mathrm{o}}$ (number of channels times the open probability) is depicted before and after basolateral $\mathrm{PGE}_{2}$ exposure for nine separate cell-attached patches at $\mathrm{V}_{\text {app }}=0 \mathrm{mV}$. Control $\mathrm{NP}_{\mathrm{o}}$ was calculated for the 3-min recording period just before $\mathrm{PGE}_{2}$ exposure (mean $\mathrm{NP}_{\mathrm{o}}$ $=0.49 \pm 0.22) . \mathrm{NP}_{\mathrm{o}}$ 's were then calculated for the 3-min recording period starting $1 \mathrm{~min}$ after basolateral membrane exposure to $0.5 \mu \mathrm{M}$ $\mathrm{PGE}_{2}$ (mean $\mathrm{NP}_{\mathrm{o}}=0.26 \pm 0.18$ ). Symbols connected by lines represent relative change in channel activity for the same cell-attached patch $\left(\right.$ mean $\mathrm{NP}_{\mathrm{o}}$ decrease $\left.=46.5 \%\right)$.

( $46.5 \%$ decrease $)(n=9)$. In contrast, comparable $\mathrm{Na}^{+}$channel inhibition was not observed when $0.5 \mu \mathrm{M} \mathrm{PGE}_{2}$ was applied to the apical membrane outside the cell-attached patch pipette $(n=12)$ (Fig. 3$)$. The change in $\mathrm{NP}_{\mathrm{o}}$ after basolateral application of $\mathrm{PGE}_{2}$ appeared specific, since neither apical ( $n$ $=4$ ) nor basolateral $(n=4)$ exposure to $0.5 \mu \mathrm{M} \mathrm{PGF}_{2 \alpha}$ resulted in channel inhibition (data not shown).

$P G E_{2}$-induced $\mathrm{Na}^{+}$channel inhibition is dependent on release of intracellular $\mathrm{Ca}^{2+}$ stores. Hebert et al. have shown that basolateral $\mathrm{PGE}_{2}$ inhibits $\mathrm{Na}^{+}$absorption in microperfused rabbit CCT by increasing intracellular $\mathrm{Ca}^{2+}$ via release from inositol triphosphate $\left(\mathrm{IP}_{3}\right)$-dependent stores (11). Thapsigargin is a cell permeable tumor promotor that rapidly releases $\mathrm{Ca}^{2+}$ from intracellular pools without hydrolysis of inositol polyphosphates (21). Basolateral bath application of $0.25 \mu \mathrm{M}$ thapsigargin inhibited $\mathrm{Na}^{+}$channel activity in single channel recordings within $1 \mathrm{~min}$ (Fig. $4 A$ ) and decreased $\mathrm{NP}_{\mathrm{o}}$ in $7 / 7$ cell-attached patches (Fig. $4 B$ ). Mean $\mathrm{NP}_{\mathrm{o}}$ fell from $0.44 \pm 0.16$ to $0.26 \pm 0.13$ ( $40.2 \%$ decrease $)$.

Rabbit CCT primary cultures were then pretreated with $0.25 \mu \mathrm{M}$ thapsigargin for $30 \mathrm{~min}$ to deplete $\left[\mathrm{Ca}^{2+}\right]_{\mathrm{i}}$ stores.
Thastrup et al. have shown that a similar pretreatment protocol abolishes intracellular $\mathrm{Ca}^{2+}$ transients elicited by $\mathrm{IP}_{3}$ or GTP (21). Baseline mean $\mathrm{NP}_{\mathrm{o}}$ for cell-attached patches in the presence of thapsigargin alone $(0.38 \pm 0.11 ; n=7)$ was not significantly different from control channel activity in principal cells grown without pretreatment (mean $\mathrm{NP}_{\mathrm{o}}=0.45 \pm 0.19 ; n=55$ ) (Figs. 2-4, 6, and 7). However, under these conditions, basolateral application of $0.5 \mu \mathrm{M} \mathrm{PGE}_{2}$ no longer inhibited $\mathrm{Na}^{+}$channel activity suggesting an important modulatory role for intracellular $\mathrm{Ca}^{2+}(n=7)$ (Fig. $5 A$ and $B$ ).

$\mathrm{Ca}^{2+}$-dependent PKC mediates $\mathrm{Na}^{+}$channel inhibition by basolateral $P G E_{2}$. Despite the apparent involvement of intracellular $\mathrm{Ca}^{2+}$, we have previously shown that $\mathrm{Na}^{+}$channel activity in principal cells of this rabbit CCT preparation is not inhibited when the cytoplasmic surface of excised inside-out patches are directly exposed to increasing free $\mathrm{Ca}^{2+}$ concentrations $\left(10^{-9}-10^{-5} \mathrm{M}\right)(3)$. One possible alternative mediator of an indirect effect of cytoplasmic $\mathrm{Ca}^{2+}$ on apical $\mathrm{Na}^{+}$permeability is $\mathrm{Ca}^{2+}$-induced activation of calcium/phospholipid-dependent PKC $(15,22)$. PKC activation by phorbol esters does inhibit $\mathrm{Na}^{+}$reabsorption in rabbit CCT at a whole tissue level and in rat CCT at a single channel level $(14,23)$.

PKC was activated by applying $0.1 \mu \mathrm{M}$ phorbol ester, $4 \beta$ phorbol 12-myristate 13-acetate $(n=5)$, or $10 \mu \mathrm{M}$ synthetic diacylglycerol, 1-oleyl-2-acetylglycerol $(n=4)$ to the apical surface of rabbit CCT primary cultures. Mean $\mathrm{NP}_{\mathrm{o}}$ for high selectivity $\mathrm{Na}^{+}$channels decreased by $44.1 \%$ (Fig. $6 A$ and $B$ ). However, basolateral application of $0.1 \mu \mathrm{M}$ PMA $(n=10)$ or $10 \mu \mathrm{M}$ OAG $(n=8)$ produced inconsistent effects on $\mathrm{Na}^{+}$ channel activity (Fig. 7). In addition, exposure of the apical membrane to $0.1 \mu \mathrm{M}$ inactive phorbol ester, $4 \alpha$-phorbol, did not affect $\mathrm{Na}^{+}$channel activity $(n=4)$ (data not shown).

To determine if the basolateral effect of $\mathrm{PGE}_{2}$ was mediated by apical PKC, we established cell-attached apical patches on primary cultures pretreated with $100 \mu \mathrm{M}$ PKC antagonist, Dsphingosine, in the apical bath for $30 \mathrm{~min}$ (24). Baseline mean $\mathrm{NP}_{\mathrm{o}}$ in the presence of $\mathrm{D}$-sphingosine alone $(0.41 \pm 0.13 ; n=8)$ was not significantly different from control channel activity in principal cells grown without pretreatment (mean $\mathrm{NP}_{\mathrm{o}}$ $=0.45 \pm 0.19 ; n=55$ ) (Figs. $2-4,6$, and 7). Subsequent exposure to $0.5 \mu \mathrm{M} \mathrm{PGE}_{2}$ on the basolateral surface resulted in no consistent reduction in $\mathrm{Na}^{+}$channel activity $(n=8)$ (Fig. $8 \mathrm{~A}$ and $B$ ).

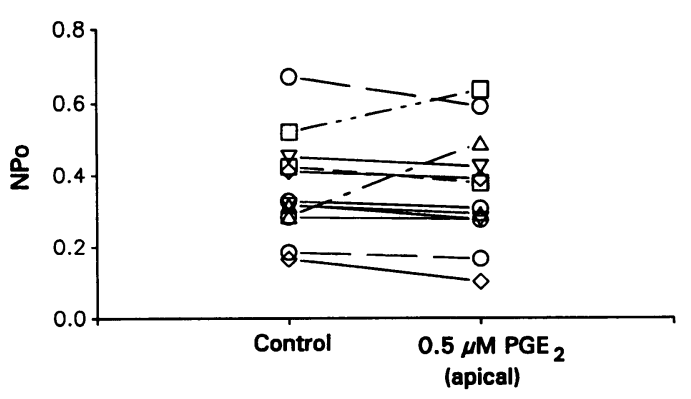

Figure 3. Effect of apical $\mathrm{PGE}_{2}$ on high selectivity $\mathrm{Na}^{+}$channels. $\mathrm{Na}^{+}$ channel activity, measured as $\mathrm{NP}_{0}$ is depicted before and after apical $0.5 \mu \mathrm{M} \mathrm{PGE}_{2}$ exposure for 12 separate cell-attached patches. Channel inhibition, similar in magnitude to basolateral $\mathrm{PGE}_{2}$ exposure, was not observed. Mean $\mathrm{NP}_{\mathrm{o}}$ did not change $(0.36 \pm 0.14$ vs. $0.36 \pm 0.16)$. 


\section{Discussion}

We have previously characterized $\mathrm{Na}^{+}$-permeable channels in principal cell apical membranes of rabbit CCT primary cultures (16) chronically exposed to aldosterone $(1.5 \mu \mathrm{M})$ and grown on permeable collagen supports $(3,17)$. The most frequently observed $\mathrm{Na}^{+}$channel (69\% of successful patches) is mineralocorticoid-dependent and sensitive to amiloride. It has a low unitary conductance $(4 \mathrm{pS})$, rectifying current-voltage (I-V) relationship, high $\mathrm{Na}^{+}$to $\mathrm{K}^{+}$permeability ratio $\left(\mathrm{P}_{\mathrm{Na}} / \mathrm{P}_{\mathrm{K}}\right.$ $>19: 1)$, long mean open times $(2.1 \pm 0.5 \mathrm{sec})$, and inward current (pipette to cell) at all applied potentials, $\mathrm{V}_{\text {app }}<+80$ $\mathrm{mV}$ (cell interior with respect to pipette interior). At resting membrane potential, mean $P_{o}$ was $0.38 \pm 0.17$, and the mean number of observed channels was $2.4 \pm 0.7$.

Several groups have demonstrated that basolateral $\mathrm{PGE}_{2}$ inhibits $\mathrm{Na}^{+}$absorption in microperfused rabbit CCT (7-11). The present study is the first to use patch clamp methods to investigate at a single channel level the mechanism for inhibition of distal nephron $\mathrm{Na}^{+}$transport by exogenous $\mathrm{PGE}_{2}$.

Apical membrane $\mathrm{Na}^{+}$channels are inhibited by basolateral membrane $P G E_{2}$ exposure. Exogenous application of 0.5 $\mu \mathrm{M} \mathrm{PGE}_{2}$ to the basolateral membrane bath resulted in a $46.5 \%$ inhibition of apical $\mathrm{Na}^{+}$channel activity $\left(\mathrm{NP}_{\mathrm{o}}\right)$ in rabbit CCT primary cultures. In vitro perfusion studies of rabbit CCT show inhibition of lumen to bath ${ }^{22} \mathrm{Na}$ flux $\left(J_{\mathrm{Na}}\right)$ ranging from 20 to $80 \%$ with peritubular bath $\mathrm{PGE}_{2}$ exposure (7-11). This large variability likely reflects the different experimental protocols used in these studies, such as the presence or absence of deoxycorticosterone, arginine vasopressin, (AVP), and meclofenate. We examined rabbit CCT cultures that had been chronically

A

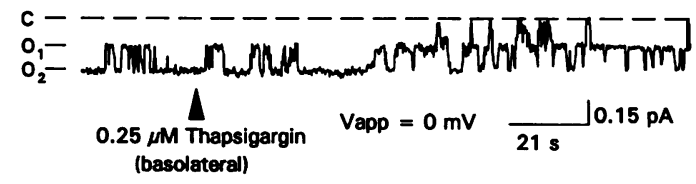

B

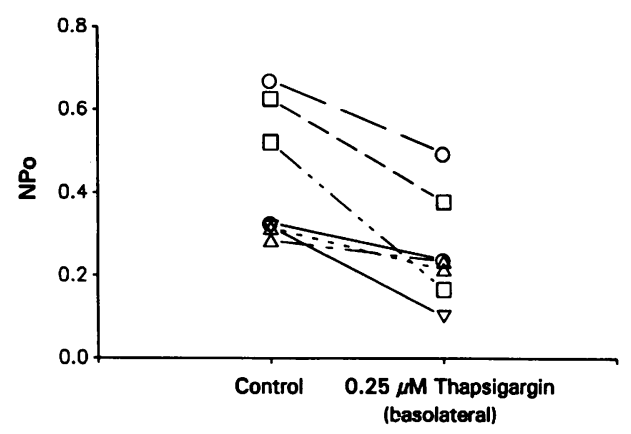

Figure 4. Effect of intracellular $\mathrm{Ca}^{2+}$ release on high selectivity $\mathrm{Na}^{+}$ channels. $(A)$ Cell-attached patch depicts the decrease in open channel activity observed after acute exposure to $0.25 \mu \mathrm{M}$ thapsigargin in the basolateral bath. $(B) \mathrm{Na}^{+}$channel activity, measured as $\mathrm{NP}_{\mathrm{o}}$, is depicted before and after basolateral thapsigargin exposure for seven separate cell-attached patches. Relative channel inhibition, similar to basolateral $\mathrm{PGE}_{2}$ exposure, was observed. Mean $\mathrm{NP}_{\mathrm{o}}$ fell from $0.44 \pm 0.16$ to $0.26 \pm 0.13$ ( $40.2 \%$ decrease $)$.
A

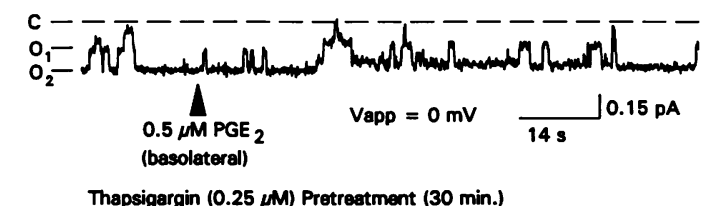

B

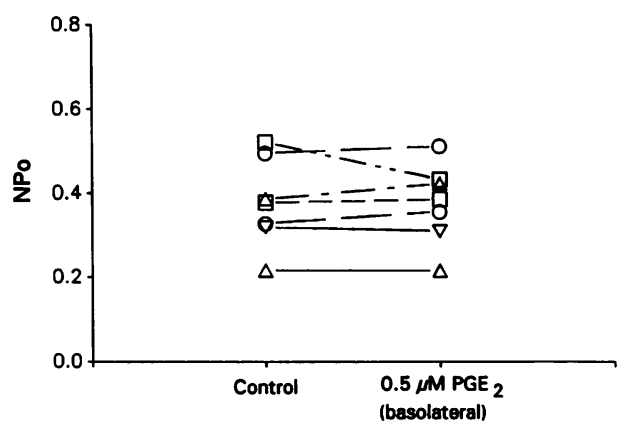

Figure 5. Effect of basolateral $\mathrm{PGE}_{2}$ after depletion of intracellular $\mathrm{Ca}^{2+}$ stores. Primary cultures were pretreated with $0.25 \mu \mathrm{M}$ thapsigargin for $30 \mathrm{~min}$. $(A)$ Cell-attached patch reflects no $\mathrm{PGE}_{2}$-induced channel inhibition after $\left[\mathrm{Ca}^{2+}\right]_{\mathrm{i}}$ pool depletion. $(B)$ Under these conditions, mean $\mathrm{NP}_{\mathrm{o}}$ did not change in seven cell-attached patches with $\mathrm{PGE}_{2}$ exposure $(0.38 \pm 0.11$ vs. $0.36 \pm 0.09)$.

exposed to aldosterone, but not exogenous AVP or cyclooygenase inhibitors.

In addition, these previous microperfusion studies used $\mathrm{PGE}_{2}$ concentrations ranging from 0.1 to $10 \mu \mathrm{M}$. $\mathrm{PGE}_{2}$ in the

A

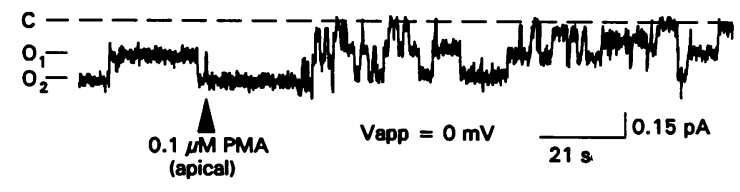

B

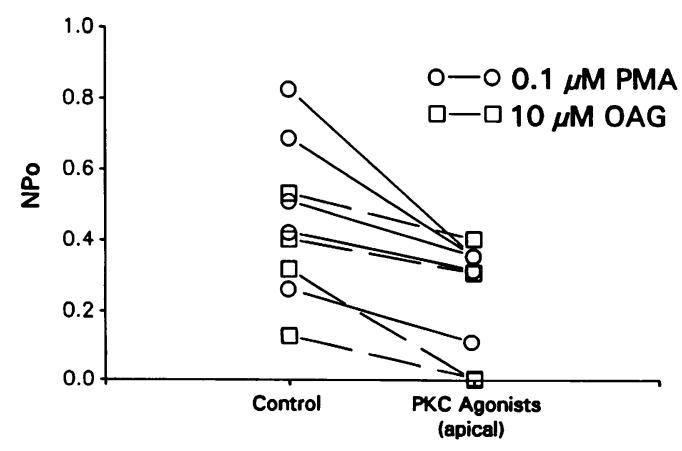

Figure 6. Effect of apical membrane exposure to PKC agonists. $(A)$ Cell-attached patch reveals increased channel closures after apical application of $0.1 \mu \mathrm{M}$ PMA. (B) Mean $\mathrm{NP}_{\mathrm{o}}$ decreased from $0.45 \pm 0.22$ to $0.25 \pm 0.16$ ( $44.1 \%$ decrease) after PKC activation by apical application of either $0.1 \mu \mathrm{M}$ PMA or $10 \mu \mathrm{M}$ OAG. 


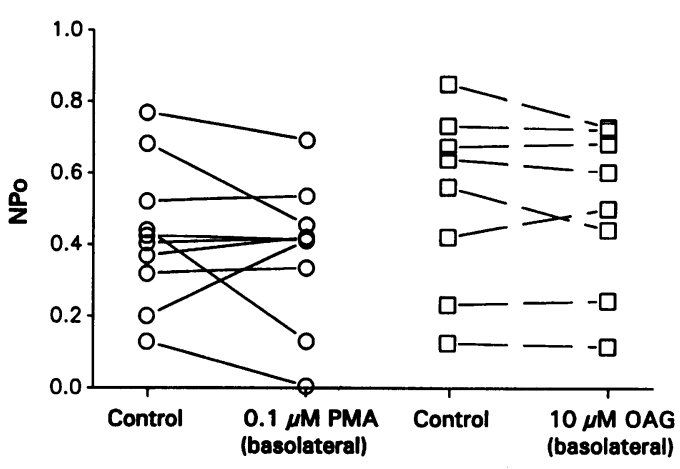

Figure 7. Effect of basolateral membrane exposure to PKC agonists. Minimal change in mean $\mathrm{NP}_{\mathrm{o}}$ was observed after PKC activation by basolateral application of $0.1 \mu \mathrm{M}$ PMA $(0.43 \pm 0.20$ to $0.38 \pm 0.19)$ or $10 \mu \mathrm{M}$ OAG $(0.53 \pm 0.25$ vs. $0.50 \pm 0.23)$.

10-100 $\mu \mathrm{M}$ range causes $50 \%$ inhibition of rabbit cortical and medullary collecting tubule $\mathrm{Na}^{+}, \mathrm{K}^{+}$-ATPase activity $(12,25)$. However, since these latter concentrations are orders of magnitude higher than the $\mathrm{PGE}_{2}$ concentration $(0.5 \mu \mathrm{M})$ that inhibited the high selectivity $\mathrm{Na}^{+}$channel, we believe that our results largely reflect inhibition of apical $\mathrm{Na}^{+}$entry rather than the basolateral $\mathrm{Na}^{+}$exit step. The physiologic range of $\mathrm{PGE}_{2}$ concentrations in the renal cortex is near $1 \mu \mathrm{M}(26)$. Marver (12) demonstrated that inhibition of basolateral $\mathrm{Na}^{+}, \mathrm{K}^{+}$-ATPase activity by $10 \mu \mathrm{M} \mathrm{PGE}_{2}$ occurs secondarily to a primary decrease in luminal $\mathrm{Na}^{+}$entry. $\mathrm{PGE}_{2}$-induced decreases in $\mathrm{Na}^{+}, \mathrm{K}^{+}$-ATPase activity were abolished if apical $\mathrm{Na}^{+}$entry was maintained with monensin (a Na${ }^{+}$ionophore). Stokes (13) also concluded that inhibition of $\mathrm{Na}^{+}$transport by $\mathrm{PGE}_{2}$ occurs at the apical $\mathrm{Na}^{+}$entry step in isolated rabbit CCT, since $\mathrm{PGE}_{2}$ increases lumen to bath $\mathrm{K}^{+}$flux similar to the effects of blocking sodium channels with amiloride, instead of decreasing $\mathrm{K}^{+}$flux as seen when $\mathrm{Na}^{+}, \mathrm{K}^{+}$-ATPase activity is blocked with ouabain.

We also observed a sidedness to the inhibitory responses of exogenous $\mathrm{PGE}_{2}$. The decrease in apical, $\mathrm{Na}^{+}$channel $\mathrm{NP}_{0}$ was larger and more consistent when applied to the basolateral rather than the apical membrane of rabbit CCT cultures. Transepithelial potential difference decreases when $\mathrm{PGE}_{2}$ is added to the peritubular but not luminal bath in isolated rabbit CCT ( 7 , $8,26)$. These observations are consistent with recent evidence, suggesting that multiple receptors for $\mathrm{PGE}_{2}$ exist in the rabbit CCT basolateral membrane $(11,27,28)$.

Release of intracellular $\mathrm{Ca}^{2+}$ stores by $\mathrm{PGE}_{2}$ indirectlymodulates $\mathrm{Na}^{+}$channel inhibition. It is well established that changes in intracellular $\mathrm{Ca}^{2+}$ modulate $\mathrm{Na}^{+}$transport in tight epithelia, including mammalian CCT $(11,15,20,22,29,30)$. $\mathrm{PGE}_{2}$ but not $\mathrm{PGF}_{2 \alpha}$ stimulates a prompt and transient increase in cytosolic $\mathrm{Ca}^{2+}$ in rabbit CCT cells that is independent of extracellular $\mathrm{Ca}^{2+}(25,29)$. This mobilization of $\left[\mathrm{Ca}^{2+}\right]_{\mathrm{i}}$ stores appears to be caused by inositolpolyphosphate hydrolysis resulting from basolateral $\mathrm{PGE}_{2}$ receptor coupling to phospholipase $C$. The $\mathrm{K}_{0.5}$ of $\mathrm{PGE}_{2}$ for this process is $0.6 \mu \mathrm{M}$, similar to the concentration we applied $(0.5 \mu \mathrm{M})$.

In our rabbit CCT cultures, the onset of $\mathrm{Na}^{+}$channel inhibition after $0.5-\mu \mathrm{M} \mathrm{PGE}_{2}$ exposure occurred within $60 \mathrm{~s}$, while in isolated rabbit CCT the peak elevation in $\left[\mathrm{Ca}^{2+}\right]_{i}$ after $0.1 \mu \mathrm{M}$ $\mathrm{PGE}_{2}$ occurs within a similar time course $(100 \mathrm{sec})(11)$. In contrast, $\mathrm{PGF}_{2 \alpha}$ exposure had no effect on high selectivity $\mathrm{Na}^{+}$ channels. We have demonstrated that release of $\mathrm{IP}_{3}$-sensitive $\left[\mathrm{Ca}^{2+}\right]_{i}$ stores by acute thapsigargin exposure also inhibits apical $\mathrm{Na}^{+}$channel activity, while previous depletion of the $\left[\mathrm{Ca}^{2+}\right]_{\mathrm{i}}$ pool with thapsigargin pretreatment attenuates or eliminates the inhibitory effect of $\mathrm{PGE}_{2}$. Pretreatment with thapsigargin alone did not affect baseline $\mathrm{Na}^{+}$channel activity in cell-attached patches, suggesting that neither thapsigargin itself nor earlier transient elevations in intracellular $\mathrm{Ca}^{2+}$ are responsible for the attenuation of basolateral $\mathrm{PGE}_{2}$ effects seen with $\left[\mathrm{Ca}^{2+}\right]_{\mathrm{i}}$ depletion. Others have shown that an inhibitor of $\left[\mathrm{Ca}^{2+}\right]_{\mathrm{i}}$ pool discharge (TMB-8) in combination with low bath $\mathrm{Ca}^{2+}$ blocks the ability of $\mathrm{PGE}_{2}$ to produce a sustained rise in $\left[\mathrm{Ca}^{2+}\right]_{\mathrm{i}}$ and reverses $\mathrm{PGE}_{2}$-induced inhibition of $J_{\mathrm{Na}}$ in isolated rabbit CCT (11).

While elevations in $\left[\mathrm{Ca}^{2+}\right]_{\mathrm{i}}$ reduce apical $\mathrm{Na}^{+}$conductance $(22,29)$, several groups, including our own, have shown no direct affect on apical $\mathrm{Na}^{+}$channel activity when excised mammalian CCT principal cell patches are exposed to increasing cytoplasmic $\mathrm{Ca}^{2+}$ concentrations $(3,22)$. These results imply that $\mathrm{PGE}_{2}$-induced elevation of $\left[\mathrm{Ca}^{2+}\right]_{\mathrm{i}}$ acts indirectly by modulating a secondary cascade of intracellular events, which, in turn, directly inhibits the apical $\mathrm{Na}^{+}$channel.

Basolateral $P G E_{2}$-induced inhibition of $\mathrm{Na}^{+}$channels is modulated by apical, $\mathrm{Ca}^{2+}$-dependent PKC. $\mathrm{Ca}^{2+} /$ phospholipid-dependent PKC is a likely candidate for mediating the indirect effect of cytoplasmic $\mathrm{Ca}^{2+}$ on apical $\mathrm{Na}^{+}$permeability. Raising epithelial cell $\left[\mathrm{Ca}^{2+}\right]_{i}$ with carbachol or the $\mathrm{Ca}^{2+}$ ionophore, A23187, results in translocation of PKC from the cytosolic to apical membrane fraction within $1 \min (29,31)$. Exposure of rabbit CCT primary cultures to the phorbol ester, PMA or synthetic diacylglycerol, OAG also promotes translocation

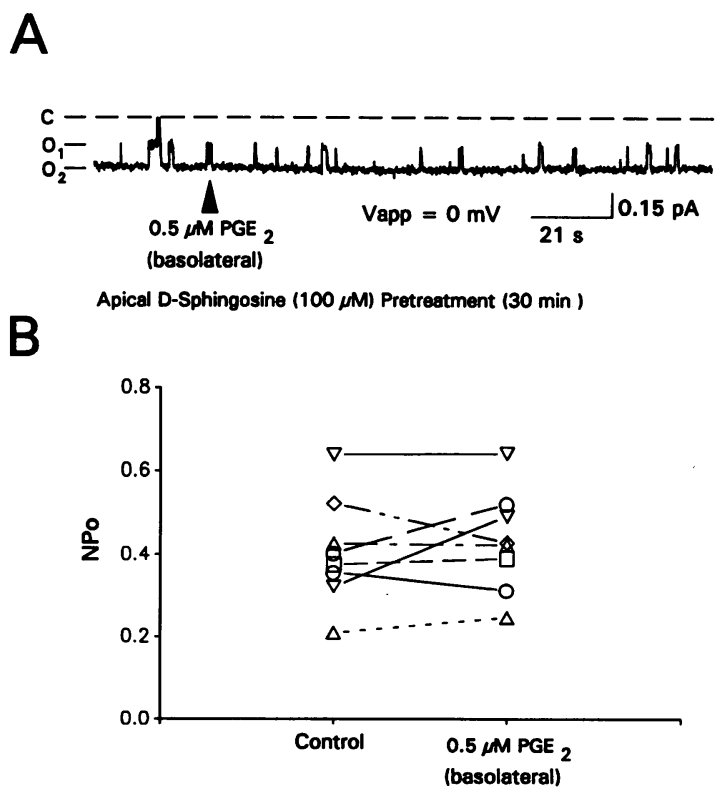

Figure 8. Effect of basolateral $\mathrm{PGE}_{2}$ after apical exposure to PKC antagonist. $(A)$ Single channel recording shows no inhibition of channel activity by $\mathrm{PGE}_{2}$ in the presence of the PKC inhibitor, Dsphingosine in the apical bath. $(B)$ Mean $N_{\mathrm{o}}$ did not decrease with $\mathrm{PGE}_{2}$ exposure after apical membrane PKC inhibition $(0.41 \pm 0.13$ vs. $0.43 \pm 0.12$ ). 
of PKC from the soluble to membrane fraction within minutes (32).

We have shown that apical exposure of rabbit CCT principal cells to PKC agonists (PMA or OAG) results in apical $\mathrm{Na}^{+}$ channel inhibition. D-sphingosine is an endogenous PKC antagonist that competitively interacts with diacylglycerol and $\mathrm{Ca}^{2+}$, and affects the regulatory domain of PKC (24). Apical pretreatment with this PKC inhibitor prevented the inhibitory effects of basolateral $\mathrm{PGE}_{2}$ on the apical $\mathrm{Na}^{+}$channel. Exposure to D-sphingosine alone did not stimulate channel activity when compared to control patches. Since all experiments were performed under conditions (i.e., permeable supports; mineralocorticoids) that promote maximal apical sodium transport, we might not expect additional $\mathrm{Na}^{+}$channel stimulation by PKC inhibition. We have not examined the effects of D-sphingosine on rabbit CCT cultures grown in the absence of aldosterone.

In contrast to apical application, basolateral PMA or OAG yielded conflicting responses with much less consistent or dramatic channel inhibition. This sidedness (apical $\gg$ basolateral) of $\mathrm{Na}^{+}$transport inhibition by PMA and OAG has also been noted by ourselves and others in A6 distal nephron cells (15, 33). We propose that basolateral membrane-associated PKC, generated from $\mathrm{PGE}_{2}$ receptor-mediated activation of phospholipase $\mathrm{C}$, does not directly mediate apical $\mathrm{Na}^{+}$channel inhibition. Instead, inositol 1,4,5-triphosphate $\left(\mathrm{IP}_{3}\right)$-mediated release of intracellular $\mathrm{Ca}^{2+}$, the other limb of $\mathrm{PGE}_{2}$-induced PLC activation, causes translocation of PKC to the apical membrane which then directly modulates apical $\mathrm{Na}^{+}$channel inhibition. These observations may explain the observation that basolateral exposure to PKC antagonists (staurosporine or H-7) alone inhibits rabbit CCT $J_{\mathrm{Na}}(11)$. Basolateral PKC is also known to feedback and inhibit the $\mathrm{PGE}_{2}$ receptor (25).

Numerous examples of ion channels modulated by phosphorylation exist $(15,34)$. PKC activation by phorbol esters inhibits sodium transport in microperfused rabbit CCT (14), and Marver (12) has demonstrated that $\mathrm{PGE}_{2}$-induced inhibition of apical $\mathrm{Na}^{+}$permeability in rabbit CCT occurs through stimulation of PKC. In the latter study, basolateral $\mathrm{Na}^{+}, \mathrm{K}^{+}$-ATPase activity falls secondary to decreased luminal $\mathrm{Na}^{+}$entry. $\mathrm{PGE}_{2}-$ and phorbol ester-induced decreases in $\mathrm{Na}^{+}, \mathrm{K}^{+}$-ATPase activity were reversed by staurosporine (a PKC inhibitor) or monensin ( $\mathrm{a} \mathrm{Na}^{+}$ionophore). We have previously shown that apical exposure to PMA or OAG decreases single $\mathrm{Na}^{+}$channel activity in $\mathrm{A} 6$ distal nephron cells, which is reversed by another PKC inhibitor, sphingosine. Cell-attached patches of freshly dissected rat CCT also show a decrease in open $\mathrm{Na}^{+}$channel density following treatment with phorbol esters (22).

Conclusion. Modulation of the high selectivity 4-pS $\mathrm{Na}^{+}$ channel in rabbit cortical collecting tubules involves a complex system constituting a three-level hierarchy of regulation: First, interaction of circulating hormone $\left(\mathrm{PGE}_{2}\right)$ with principal cell basolateral membrane receptors stimulates basolateral effectors (phospholipase C); second, activation of intracellular signalling cascades ( $\mathrm{IP}_{3}$-sensitive $\mathrm{Ca}^{2+}$ pool release) transduce basolateral membrane signals to the apical membrane; and finally, the third level of regulation occurs at a molecular level within the apical membrane and involves second messenger (PKC) interaction with apical membrane-associated molecules including the $\mathrm{Na}^{+}$channel protein itself.

\section{Acknowledgments}

The authors are indebted to Christine L. Webster for her skillful technical assistance in the preparation of the rabbit cortical collecting tubule primary cultures.

Brian N. Ling was supported by Veterans Administration Merit Review Award and National Institutes of Health (NIH) Biomedical Research Support grant S07 RR05364. Douglas C. Eaton was supported by NIH Grant DK-37963.

\section{References}

1. O'Neil, R. G. 1990. Aldosterone regulation of sodium and potassium transport in the cortical collecting duct. Semin. Nephrol. 10:365-374.

2. Ling, B. N., A. E. Kemendy, K. E. Kokko, C. F. Hinton, Y. Marunaka, and D. C. Eaton. 1990. Regulation of the amiloride-blockable sodium channel from epithelial tissue. Mol. Cell Biochem. 99:141-150.

3. Ling, B. N., C. F. Hinton, and D. C. Eaton. 1991. Amiloride-sensitive sodium channels in rabbit cortical collecting tubule primary cultures. $A m$. J. Physiol. 261:F333-F344.

4. Eaton, D. C., Y. Marunaka, and B. N. Ling. 1992. Ion channels in epithelial tissue: single-channel properties. In Membrane Transport in Biology. J. A. Schafer, H. H. Ussing, P. Kristensen, and G. H. Giebisch, editors. Springer-Verlag, Berlin. 73-165.

5. Eaton, D. C., and K. L. Hamilton. 1988. The amiloride-blockable sodium channel of epithelial tissue. In Ion Channels. T. Narahashi, editor. Plenum Publishing Corporation, New York. 251-282.

6. Smith, P. R., and D. J. Benos. 1991. Epithelial $\mathrm{Na}^{+}$channels. In Annual Review of Physiology. J. F. Hoffman and P. De Weer, editors. Annual Reviews Inc., Palo Alto, CA. 509-530.

7. Stokes, J. B., and J. P. Kokko. 1977. Inhibition of sodium transport by prostaglandin $\mathrm{E}_{2}$ across the isolated, perfused rabbit collecting tubule. J. Clin. Invest. 59:1099-1104.

8. lino, Y., and M. Imai: 1978. Effects of prostaglandins on $\mathrm{Na}$ transport in isolated collecting tubules. Pflugers Arch. Gesamte Physiol Menschen Tiere. 373:125-132.

9. Holt, W. F., and C. Lechene. 1981. ADH-PGE 2 interactions in cortical collecting tubule. I. Depression of sodium transport. Am. J. Physiol. 241:F452F460.

10. Chen, L., M. C. Reif, and J. A. Schafer. 1991. Clonidine and PGE 2 have different effects on $\mathrm{Na}^{+}$and water transport in rat and rabbit CCD. Am. J. Physiol. 261:F126-F136.

11. Hebert, R. L., H. R. Jacobson, and M. D. Breyer. 1991. Prostaglandin $E_{2}$ inhibits sodium transport in rabbit cortical collecting duct by increasing intracellular calcium. J. Clin. Invest. 87:1992-1998.

12. Marver, D. 1990. PGE2 and PMA inhibit rabbit CCT (Na,K)-ATPase activity by a primary effect on luminal membrane Na permeability. Kidney Int. 37:349. (Abstr.)

13. Stokes, J. B. 1986. Patterns of $\mathrm{K}^{+}$permeation following inhibition of $\mathrm{Na}^{+}$ transport in rabbit cortical collecting tubule. Am. J. Physiol. 250:F120-F126.

14. Hays, S. R., M. Baum, and J. P. Kokko. 1987. Effects of protein kinase C activation on sodium, potassium, chloride, and total $\mathrm{CO}_{2}$ transport in the rabbit cortical collecting tubule. J. Clin. Invest. 80:1561-1570.

15. Ling, B. N., and D. C. Eaton. 1989. Effects of luminal $\mathrm{Na}^{+}$on single $\mathrm{Na}^{+}$ channels in A6 cells, a regulatory role for protein kinase C. Am. J. Physiol. 256:F1094-F1103.

16. Bello-Reuss, E., and M. R. Weber. 1987. Electrophysiological studies of primary cultures of rabbit distal tubule cells. Am. J. Physiol. 252:F899-F909.

17. Ling, B. N., C. F. Hinton, and D. C. Eaton. 1991. Potassium permeable channels in primary cultures of rabbit cortical collecting tubule. Kidney Int. 40:441-452.

18. Ling, B. N., C. L. Webster, and D. C. Eaton. 1992. Eicosanoids modulate apical $\mathrm{Ca}^{2+}$-dependent $\mathrm{K}^{+}$channels in cultured rabbit principal cells. Am. J. Physiol. 263:F116-F126.

19. Marunaka, Y., and D. C. Eaton. 1991. Effects of vasopressin and cAMP on single amiloride-blockable Na channels. Am. J. Physiol. 260:C1071-C1084.

20. Palmer, L. G., and G. Frindt. 1987. Effects of cell $\mathrm{Ca}$ and $\mathrm{pH}$ on $\mathrm{Na}$ channels from rat cortical collecting tubule. Am. J. Physiol. 253:F333-F339.

21. Thastrup, O., P. J. Cullen, B. K. Drobak, M. R. Hanley, and A. P. Dawson. 1990. Thapsigargin, a tumor promotor, discharges intracellular Ca stores by specific inhibition of the endoplasmic reticulum Ca-ATPase. Proc. Natl. Acad. Sci. USA. 87:2466-2470.

22. Turnheim, K. 1991. Intrinsic regulation of apical sodium entry in epithelia. Physiol. Rev. 71:429-445.

23. Palmer, L. G., and G. Frindt. 1987. Ca ionophore and phorbol ester inhibit Na channels in rat cortical tubules. Fed. Proc. 46:495. (Abstr.) 
24. Hannun, Y. A., and R. M. Bell. 1987. Mechanism of activation of protein kinase c: role of diacylglycerol and calcium second messengers. In Cell Calcium and the Control of Membrane Transport. L. J. Mandel and D. C. Eaton, editors. Rockefeller University Press, New York. 229-239.

25. Bonventre, J. V., and R. Nemenoff. 1991. Renal tubular arachidonic acid metabolism. Kidney Int. 39:438-449.

26. Kokko, J. P. 1981. Effect of prostaglandins on renal epithelial electrolyte transport. Kidney Int. 19:791-796.

27. Plante, G. E., M. D. Breyer, H. R. Jacobson, and R. L. Hebert. 1991 Distinct effects of PGE2 and the receptor selective PGE2 analogue sulprostone (SLP) on renal hemodynamics, urine volume and $\mathrm{Na}^{+}$excretion in the rabbit. $J$. Am. Soc. Nephrol. 2:525. (Abstr.)

28. Hebert, R. L., H. R. Jacobson, and M. D. Breyer. 1990. The PGE2 analogue sulprostone confirms separate receptors mediate PGE2's inhibition of water flow and $\mathrm{Na}^{+}$transport in the cortical collecting duct (CCD). J. Am. Soc Nephrol. 1:471. (Abstr.)
29. Breyer, M. D. 1991. Regulation of water and salt transport in collecting duct through calcium-dependent signaling mechanisms. Am. J. Physiol. 260:F1F11.

30. Frindt, G., and E. E. Windhager. $1990 . \mathrm{Ca}^{2+}$-dependent inhibition of sodium transport in rabbit cortical collecting tubules. Am. J. Physiol. 258:F568F582.

31. Cohen, M. E., J. Wesolek, J. McCullen, K. Rys-Sikora, S. Pandol, and R. P. Rood. 1991. Carbachol and elevated $\mathrm{Ca}^{2+}$-induced translocation of functionally active protein kinase $\mathrm{C}$ to the brush border of rabbit ileal $\mathrm{Na}^{+}$absorbing cells. J. Clin. Invest. 88:855-863.

32. Dixon, B. S., R. Breckon, C. Burke, and R. J. Anderson. 1988. Phorbol esters inhibit adenylate cyclase activity in cultured collecting tubular cells. Am. J. Physiol. 254:C183-C191.

33. Yanase, M., and J. S. Handler. 1986. Activators of protein kinase Cinhibit sodium transport in A6 epithelia. Am. J. Physiol. 250:C517-C522.

34. Levitan, I. B. 1985. Phosphorylation of ion channels. J. Membr. Biol. 87:177-190. 